\title{
Cultivar differences of black scurf occurrence on potato tubers
}

\section{Odmianowe zróżnicowanie występowania ospowatości bulw ziemniaka}

\author{
Barbara Lutomirska*, Joanna Jankowska
}

\section{Summary}

Nowadays the potato skin diseases are very important factors limiting the quality of tubers. The skin diseases include also the black scurf that results from the occurrence of Rhizoctonia solani sclerotia. The study used the data regarding evaluation of infected tubers and degree of infected tubers of black scurf on the potato cultivars in 2001-2013, which were collected during the experiments in Potato Agronomy Department, at the Plant Breeding and Acclimatization Institute - National Research Institute, Division in Jadwisin, Poland. The study included 165 potato cultivars, evaluated for a period of three years or more. As a result of experiments it was found, that the share tubers with black scurf and the severity of ocurrence of $R$. solani sclerotia on tubers were determinded by the cultivar factors. Futhermore, it was shown that the cultivar differentiation of tubers with black scurf was formed differently than the cultivar diversity of the severity of sclerotia on the tubers. The most infected tubers were recorded in early cultivar

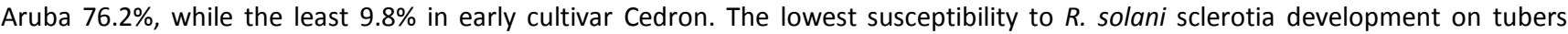
appeared in medium early variety Roksana - 7.1 degrees, and the highest severity of disease symptoms 3.3 degrees was observed on tubers of early variety Gracja.

Key words: potato; black scurf occurrence; cultivars

\section{Streszczenie}

Choroby skórki stanowią aktualnie jeden z istotnych czynników ograniczających jakość bulw ziemniaka. Zalicza się do nich także ospowatość bulw będącą efektem występowania sklerocjów grzyba Rhizoctonia solani. W badaniach wykorzystano wyniki oceny odmian dotyczące udziału bulw z ospowatością oraz nasilenia sklerocjów na bulwach uzyskane w doświadczeniach odmianowych zrealizowanych w latach 2001-2013, w Zakładzie Agronomii Ziemniaka, Instytutu Hodowli i Aklimatyzacji Roślin - Państwowego Instytutu Badawczego w Jadwisinie. W opracowaniu uwzględnione zostały dane dotyczące 165 odmian ocenianych przez okres nie krótszy niż 3 lata. Wyniki badań wskazują, że zarówno udział bulw z ospowatością, jak i stopień nasilenia sklerocjów grzyba $R$. solani na bulwach były uwarunkowane przez czynnik odmianowy. Najwyższy udział bulw z ospowatością zanotowano u wczesnej odmiany Aruba $76,2 \%$, najniższy - 9,8\% u odmiany Cedron. Najmniejszą podatnością na namnażanie sklerocjów grzyba $R$. solani na bulwach potomnych wyróżniła się odmiana średnio wczesna Roksana, stopień porażenia bulw - 7,1, natomiast najwyższe nasilenie objawów choroby - stopień porażenia bulw 3,3 obserwowano u odmiany wczesnej Gracja.

Słowa kluczowe: ziemniak; występowanie ospowatości bulw; odmiany

Instytut Hodowli i Aklimatyzacji Roślin - Państwowy Instytut Badawczy

Oddział w Jadwisinie

Szaniawskiego 15, 05-140 Jadwisin

*corresponding author: b.lutomirska@ihar.edu.pl 


\section{Wstęp / Introduction}

Choroby skórki bulw stanowią coraz większy problemem w produkcji ziemniaka. Jednym z powszechnie występujących sprawców takich zmian jest grzyb Rhizoctonia solani. Właściwa temu patogenowi zdolność rozwoju zarówno na roślinach, jak i bulwach prowadzi do ograniczenia ilości oraz pogorszenia jakości plonu. Przyczyną strat ilościowych są przede wszystkim zgorzel kiełków i próchnienie podstawy łodyg stanowiące następstwo infekcji, do jakich dochodzi we wczesnych fazach rozwoju roślin. Wymienione objawy chorobowe zwykle nie doprowadzaja do całkowitego zniszczenia młodej rośliny, ale ograniczają jej możliwości plonotwórcze, a ponadto powodują niekorzystne zmiany w strukturze plonu i morfologii bulw. Efektem porażenia młodych roślin przez $R$. solani są nekrotyczne zmiany na stolonach i zawiązkach, które w dalszych etapach rozwoju prowadzą do wykształcania się bulw zdeformowanych najczęściej $\mathrm{z}$ charakterystycznymi spłaszczeniami (kanciastościami) bądź spękaniami. Innym symptomem infekcji jest gruba, głęboko spękana skórka określana, jako „skórka słoniowata” (Kućmierz i wsp. 1993; Lutomirska 2010). Nieprawidłowości powodowane przez $R$. solani zaliczane do chorób skórki to występujące na powierzchni bulw skupiska grzybni przetrwalnikowej - sklerocja, określane jako ospowatość. Jak wynika z prac różnych autorów, straty wielkości i jakości plonu wynikające $\mathrm{z}$ infekcji patogenem mogą wynosić od kilku do nawet 50\% (Platt i wsp. 1993; Kochman i Węgorek 1997; Häni i wsp. 1998). Źródło choroby w kolejnych sezonach wegetacyjnych stanowią zarówno sklerocja występujące na sadzeniakach, jak i pozostające na resztkach roślinnych w glebie (Tsror 2010). Woodhall i wsp. (2008), a także Lehtonen (2009) stwierdzili, że spośród 14 grup anastomozowych $R$. solani największą zdolnością porażania ziemniaka i tworzenia sklerocjów na bulwach wyróżnia się patotyp AG3. Jak wykazały badania w kraju, podobnie jak $\mathrm{w}$ innych krajach europejskich, jest on patotypem dominującym (Woodall i wsp. 2013). Najprostszym sposobem ograniczania strat powodowanych przez $R$. solani jest stosowanie zabiegów chemicznych. Aplikacja odpowiednich fungicydów zgodnie $\mathrm{z}$ zaleceniami może być prowadzona przez zaprawianie sadzeniaków bądź stosowana doglebowo w formie oprysku gleby podczas sadzenia.

Konieczność ograniczania zabiegów chemicznych wynikająca $\mathrm{z}$ wprowadzenia obowiązku stosowania zasad integrowanej ochrony, a także całkowity zakaz ich wykorzystywania w uprawach prowadzonych metodami ekologicznymi, zobowiązują do poszukiwania innych możliwości zmniejszania strat związanych $\mathrm{z}$ występowaniem objawów rozwoju patogenów. W takiej sytuacji, poza stosowaniem ograniczających zagrożenie chorobą rozwiązań agrotechnicznych, uzasadnionym byłoby wykorzystywanie genetycznie uwarunkowanej odporności. Genotypowe zróżnicowanie występowania objawów porażenia przez $R$. solani na roślinach i bulwach ziemniaka wykazali m.in.: Choroszewski (1993), Bains i wsp. (2002), Lenc (2006), Tsror (2010), Djébali i Tarhouni (2010), Tsror (2010), Lutomirska i Jankowska (2013).
Celem badań była ocena genotypowej zmienności występowania ospowatości bulw u odmian ziemniaka różnych wczesności wpisywanych do Krajowego Rejestru. Zweryfikowano także pojawiające się tezy dotyczące zależności między kierunkiem użytkowania genotypów i ich skłonnością do występowania ospowatości, a także między miejscem wyhodowania (krajowe/zagraniczne) a ocenianą cechą.

\section{Materiały i metody / Materials and methods}

Badania przeprowadzono wykorzystując dane uzyskane podczas prowadzenia doświadczeń odmianowych zrealizowanych w latach 2001-2013, w Zakładzie Agronomii Ziemniaka Instytutu Hodowli i Aklimatyzacji Roślin Państwowego Instytutu Badawczego w Jadwisinie. W kolejnych latach badań w każdej z grup wczesności oceniano od 5 do 30 odmian, a liczba genotypów badanych w kolejnych latach wynosiła od 42 do 64 . Ogółem w badaniach uwzględniono 172 odmiany, natomiast w prezentowanym opracowaniu uwzględnione zostały tylko te, które były oceniane przez okres nie krótszy niż 3 lata. Ich łączna liczba to 165 (tab. 1).

Doświadczenia polowe prowadzono $\mathrm{z}$ zastosowaniem standardowej agrotechniki. We wszystkich latach badań nawożenie organiczne stanowiła słoma pszenicy uprawianej w plonie głównym oraz masa zielona gorczycy białej uprawianej jako poplon, natomiast $\mathrm{w}$ nawozach mineralnych (na $1 \mathrm{ha}$ ) wnoszono około $92 \mathrm{~kg} \mathrm{~N}, 41 \mathrm{~kg}$ P i $112 \mathrm{~kg}$ K. Sadzenie ziemniaków odmian wszystkich wczesności było wykonywane w III dekadzie kwietnia, najczęściej 24. lub 25. dnia miesiąca. Przygotowane do tego celu sadzeniaki nie były poddawane zabiegowi zaprawiania. W doświadczeniach stosowano pielęgnację mechanicznochemiczną oraz zależnie od potrzeb ochrony roślin w warunkach poszczególnych sezonów wegetacyjnych - zabiegi nalistne przeciw stonce ziemniaczanej i sprawcom chorób epidemicznych. Podczas zbiorów przeprowadzanych w fazie pełni dojrzałości odmian określonej wczesności, z każdego powtórzenia polowego pobierane były próby bulw przeznaczone do oceny występowania chorób skórki. W składzie próby nie uwzględniano bulw frakcji poniżej $35 \mathrm{~mm}$, jej masa wynosiła około $8 \mathrm{~kg}$. Ocena ospowatości, w 9-stopniowej skali, wykonywana zgodnie z metodyką opracowaną w Instytucie Hodowli i Aklimatyzacji Roślin (Roztropowicz 1999) miała miejsce do 2 tygodni po zbiorze. Wyniki indywidualnej oceny bulw stanowiły podstawę wyliczenia średniego stopnia porażenia oraz procentowego udziału bulw porażonych (Townsend i Heuberger 1943).

Uzyskane dane poddano analizom wariancji korzystając z programu SAS Enterprise Guide 4.3. Istotność zróżnicowania odmian testowano testem Tukeya na poziomie $\mathrm{p}=0,05$.

\section{Wyniki i dyskusja / Results and discussion}

Wyniki badań wskazują, że zarówno udział bulw z ospowatością, jak i stopień nasilenia sklerocjów grzyba 
$R$. solani na bulwach był uwarunkowany przez czynnik odmianowy oraz czynniki środowiska - lata badań (tab. 2). Tym samym stanowią one potwierdzenie zależności prezentowanych $\mathrm{w}$ literaturze przedmiotu, w tym także w badaniach własnych (Pietkiewicz i Choroszewski 1983; Djébali i Tarhouni 2010; Lutomirska i Jankowska 2013). Ponadto stwierdzono, że we wszystkich grupach wczesności miejsce wykreowania genotypów nie miało wpływu na ich podatność na występowanie ospowatości. Natomiast istotne zróżnicowanie udziału bulw $\mathrm{z}$ ospowatością oraz nasilenia sklerocjów na bulwach odmian jadalnych i skrobiowych odnotowano jedynie u odmian późnych (tab. 2).

Stwierdzono także, że średnio najwyższy udział bulw ze sklerocjami notowano u odmian bardzo wczesnych $48,6 \%$, najniższy u odmian średnio wczesnych - 35,8\% (tab. 3). Jednocześnie średni stopień porażenia bulw odmian obu wymienionych grup kształtował się bardzo podobnie, u odmian bardzo wczesnych wyniósł - 5,9, u średnio wczesnych - 5,8. Największe nasilenie sklerocjów na bulwach, czyli najniższą wartość stopnia porażenia odnotowano $\mathrm{w}$ przypadku odmian wczesnych $-5,5$, a najwyższą (tj. najmniejsze występowanie sklerocjów) - 6,1 u odmian późnych (tab. 3).

Ocena odmianowego zróżnicowania parametrów ospowatości przeprowadzona metodą grupowania Tukeya pozwala wnioskować, że poziom ich genotypowej zmienności układa się odmiennie w poszczególnych grupach wczesności odmian. Stwierdzono, że liczby grup odmian jednorodnych pod względem udziału bulw z ospowatością, a także stopnia porażenia bulw kształtowały się różnie. Najwięcej klas jednorodnych, czyli największe zróżnicowanie odmianowe pod względem udziału bulw $\mathrm{z}$ ospowatością odnotowano w grupie odmian wczesnych 6 grup, natomiast wyraźnie mniejsze - po 2 klasy w grupach odmian średnio wczesnych i późnych (tab. 3). Liczba klas odmian jednorodnych pod względem stopnia porażenia bulw wynosiła od 1 dla grupy odmian późnych do 6 dla odmian średnio wczesnych (tab. 3). Liczby klas odmian jednorodnych pod względem ocenianych parametrów nie były związane z liczbą odmian poszczególnych wczesności poddanych ocenie (tab. 1, 3).

Powyższe wyniki wskazują także, że genotypowa zmienność ocenianych parametrów układa się odmiennie, czyli są one niezależne. Oznacza to, że np. odmiana o niskim udziale bulw ze sklerocjami nie zawsze charakteryzuje się małym ich nasileniem na bulwach. Spośród ocenionych 165 genotypów, najwyższy udział bulw z ospowatością zanotowano u wczesnej odmiany Aruba - 76,2\% (rys. 1). Najniższym udziałem bulw z omawianą chorobą skórki 9,8\% charakteryzowała się należąca do tej samej grupy wczesności odmiana Cedron (rys. 2). Najmniejszą podatnością na namnażanie sklerocjów grzyba $R$. solani na bulwach potomnych wyróżniła się odmiana średnio wczesna Roksana $-7,1^{\circ}$, a najwyższe nasilenie objawów choroby obserwowano na bulwach odmiany wczesnej Gracja $3,3^{\circ}$ (rys. 3,4 ). Odmianami o niskim udziale bulw porażonych przy równie niskim nasileniu patogena okazały się: Danusia, Hinga, Ślęza, Tara, Viviana, Wolfram i Zagłoba (rys. 1, 2). Wykazana w niniejszych badaniach niska skłonność odmiany Danusia do występowania ospowatości bulw jest zgodna $\mathrm{z}$ wynikami oceny tej odmiany przedstawionymi przez Bernata (2005). W odniesieniu do innej odmiany (Wolfram), także uwzględnionej we wspomnianych badaniach, nie ma potwierdzenia dla uzyskanego wyniku. Odmianami o wysokiej podatności/skłonności do występowania ospowatości, w świetle prezentowanych wyników są odmiany: Molli, Felka Bona, Gracja. Na niekorzystny, wysoki poziom występowania ospowatości u odmiany Gracja wskazują wcześniejsze wyniki badań Lutomirskiej (2007). Odnotowane w warunkach badań genotypowe różnice udziału bulw z ospowatością są też w pewnym zakresie zgodne $\mathrm{z}$ wynikami badaczek litewskich Turki i Bimšteine (2011). Oceniając dużą liczbę 75 odmian, wśród których znalazły się także niektóre $\mathrm{z}$ uwzględnionych $\mathrm{w}$ analizowanym zestawie, wspomniane autorki stwierdziły m.in., że niemal u połowy z badanych 37 odmian nie wystąpiły bulwy ze sklerocjami, a u 5 innych udział bulw porażonych był niski. Wśród odmian, u których nie odnotowano bulw porażonych wymieniana jest między innymi odmiana Velox, która w przedstawionych badaniach należała do grupy odmian o najniższym udziale bulw ze sklerocjami, zaś zaliczona do grupy odmian o najwyższym udziale bulw ospowatych Ewelina wyróżniła się także w warunkach litewskich dość wysokim $(20 \%)$ ich udziałem.

Tabela 1. Liczba odmian ziemniaka ocenianych w latach badań 2001-2013

Table 1. Number of potato cultivars evaluated in the years of the study 2001-2013

\begin{tabular}{|c|c|c|c|c|c|c|}
\hline $\begin{array}{l}\text { Grupa wczesności } \\
\text { Maturity group }\end{array}$ & $\begin{array}{l}\text { Bardzo wczesne } \\
\text { Very early }\end{array}$ & $\begin{array}{l}\text { Wczesne } \\
\text { Early }\end{array}$ & $\begin{array}{l}\text { Średnio wczesne } \\
\text { Medium early }\end{array}$ & $\begin{array}{l}\text { Średnio późne } \\
\text { Medium late }\end{array}$ & $\begin{array}{l}\text { Późne } \\
\text { Late }\end{array}$ & $\begin{array}{l}\text { Łącznie w roku } \\
\text { Total in the year }\end{array}$ \\
\hline $\begin{array}{l}\text { Liczba odmian ocenianych } \\
\text { w kolejnych latach badań } \\
\text { Number of cultivars } \\
\text { evaluated in the following } \\
\text { years of the study }\end{array}$ & $7-10$ & $7-13$ & $17-30$ & $5-11$ & $5-13$ & $42-64$ \\
\hline $\begin{array}{l}\text { Liczba odmian } \\
\text { uwzględnionych } \\
\text { w analizie (przynajmniej } \\
\text { 3-letni okres badań) } \\
\text { Number of cultivars } \\
\text { included in the analysis (at } \\
\text { least 3-years of research) }\end{array}$ & 19 & 25 & 67 & 25 & 29 & 165 \\
\hline
\end{tabular}


Tabela 2. Istotność oddziaływania czynników na występowanie ospowatości bulw ziemniaka

Table 2. The significance of the impact factors of black scurf occurrences on tubers of the potato

\begin{tabular}{|c|c|c|c|c|c|}
\hline $\begin{array}{l}\text { Grupa wczesności } \\
\text { Maturity group }\end{array}$ & $\begin{array}{l}\text { Bardzo wczesne } \\
\text { Very early }\end{array}$ & $\begin{array}{l}\text { Wczesne } \\
\text { Early }\end{array}$ & $\begin{array}{l}\text { Średnio wczesne } \\
\text { Medium early }\end{array}$ & $\begin{array}{l}\text { Średnio późne } \\
\text { Medium late }\end{array}$ & $\begin{array}{l}\text { Późne } \\
\text { Late }\end{array}$ \\
\hline \multicolumn{6}{|c|}{ Udział bulw porażonych - Share of infected tubers [\%] } \\
\hline Odmiana-Cultivar & $*$ & $*$ & $*$ & $*$ & $*$ \\
\hline Rok - Year & $*$ & $*$ & $*$ & $*$ & $*$ \\
\hline Kierunek użytkowania - Suitability & - & - & - & - & $*$ \\
\hline Pochodzenie - Origin of breeding & - & - & - & - & - \\
\hline Współdziałanie - Interaction & $*$ & $*$ & $*$ & $*$ & $*$ \\
\hline \multicolumn{6}{|c|}{ Stopień porażenia bulw - Degree of infected tubers $\left[9^{\circ}\right]$} \\
\hline Odmiana-Cultivar & $*$ & $*$ & $*$ & $*$ & $*$ \\
\hline Rok - Year & * & * & * & $*$ & $*$ \\
\hline Kierunek użytkowania - Suitability & - & - & - & - & $*$ \\
\hline Pochodzenie - Origin of breeding & - & - & - & - & - \\
\hline Współdziałanie - Interaction & $*$ & $*$ & $*$ & - & $*$ \\
\hline
\end{tabular}

*statystycznie istotne różnice - significant difference

Tabela 3. Udział bulw porażonych i indeks porażenia bulw w poszczególnych grupach wczesności w latach 2001-2013

Table 3. Share of infected tubers and degree of infected tubers of different maturity groups in years 2001-2013

\begin{tabular}{|c|c|c|c|c|c|c|}
\hline \multicolumn{2}{|c|}{$\begin{array}{l}\text { Grupa wczesności } \\
\text { Maturity group }\end{array}$} & $\begin{array}{l}\text { Bardzo wczesne } \\
\text { Very early }\end{array}$ & $\begin{array}{l}\text { Wczesne } \\
\text { Early }\end{array}$ & $\begin{array}{l}\text { Średnio wczesne } \\
\text { Medium early }\end{array}$ & $\begin{array}{l}\text { Średnio późne } \\
\text { Medium late }\end{array}$ & $\begin{array}{l}\text { Późne } \\
\text { Late }\end{array}$ \\
\hline \multirow{3}{*}{$\begin{array}{l}\text { Udział bulw } \\
\text { porażonych } \\
\text { Share of infected } \\
\text { tubers } \\
{[\%]}\end{array}$} & średnia - mean & 48,6 & 37,6 & 35,8 & 39,4 & 40,0 \\
\hline & $\begin{array}{l}\operatorname{NIR}(0,05) \\
\operatorname{LSD}(0.05)\end{array}$ & 28,5 & 27,9 & 35,3 & 32,2 & 28,0 \\
\hline & $\begin{array}{l}\text { liczba klas jednorodnych } \\
\text { the number of classes } \\
\text { of homogeneous }\end{array}$ & 5 & 6 & 2 & 5 & 2 \\
\hline \multirow{3}{*}{$\begin{array}{l}\text { Stopień } \\
\text { porażenia bulw } \\
\text { Degree of infected } \\
\text { tubers } \\
{\left[9^{\circ}\right]}\end{array}$} & średnia - mean & 5,9 & 5,5 & 5,8 & 5,9 & 6,1 \\
\hline & $\begin{array}{l}\operatorname{NIR}(0,05) \\
\operatorname{LSD}(0.05)\end{array}$ & 1,4 & 2,0 & 2,2 & 2,0 & 1,6 \\
\hline & $\begin{array}{l}\text { liczba klas jednorodnych } \\
\text { the number of classes } \\
\text { of homogeneous }\end{array}$ & 3 & 4 & 6 & 3 & 1 \\
\hline
\end{tabular}

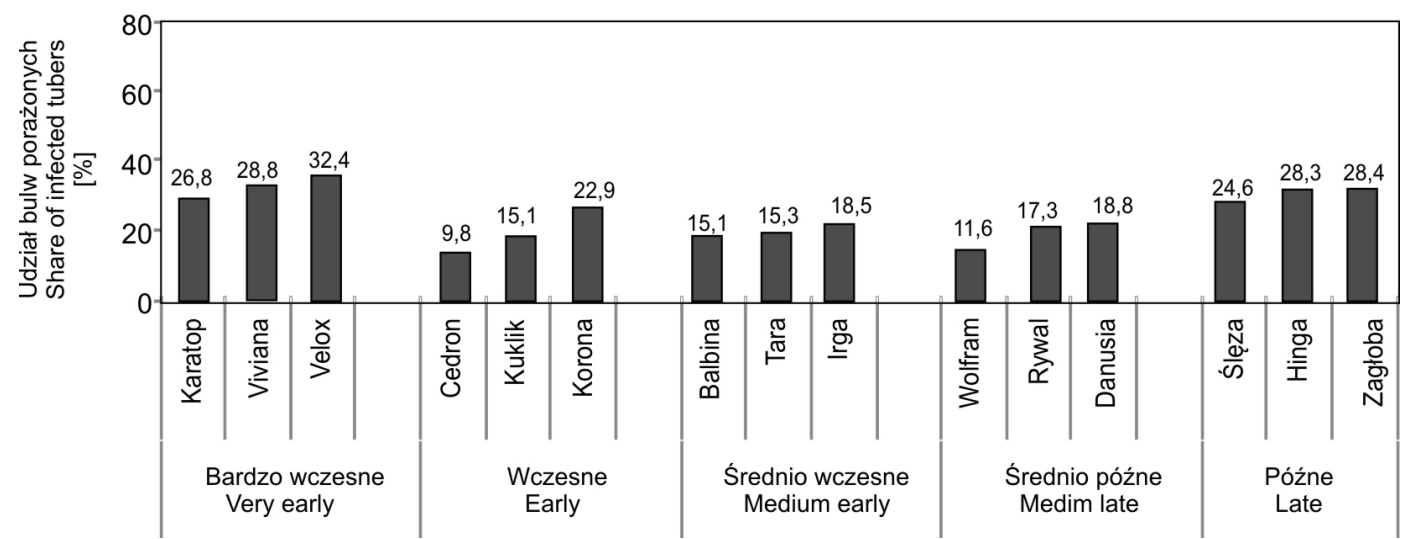

Rys. 1. Odmiany o najniższym udziale bulw porażonych [\%]

Fig. 1. The cultivars with the lowest share of infected tubers [\%] 


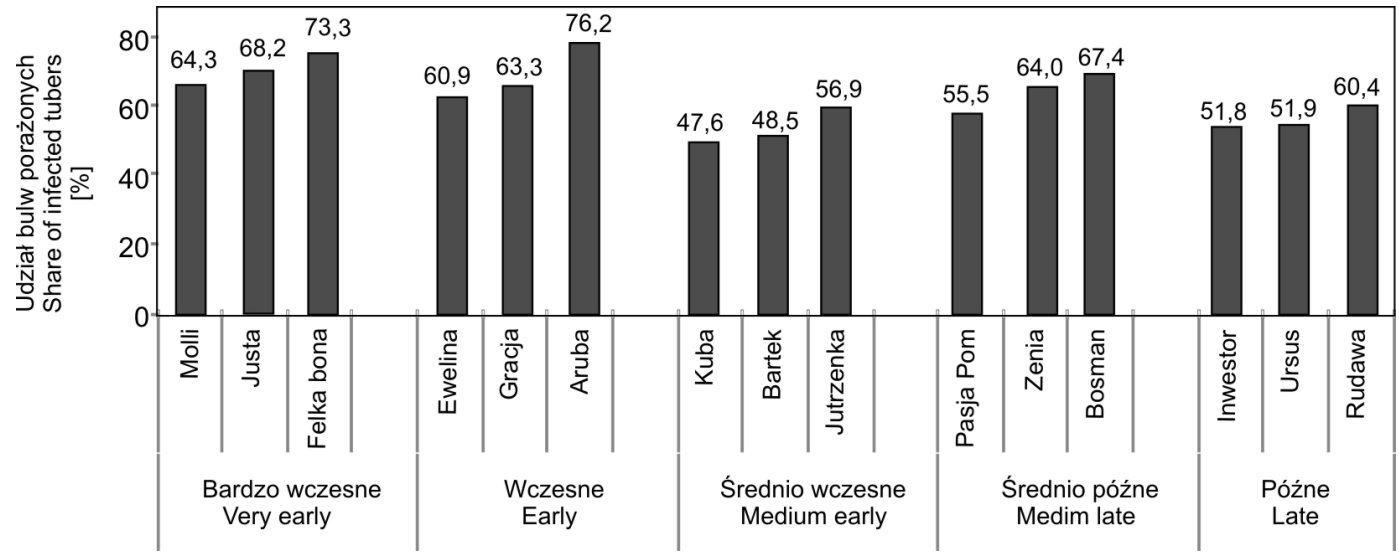

Rys. 2. Odmiany o najwyższym udziale bulw porażonych [\%]

Fig. 2. The cultivars with the highest share of infected tubers [\%]

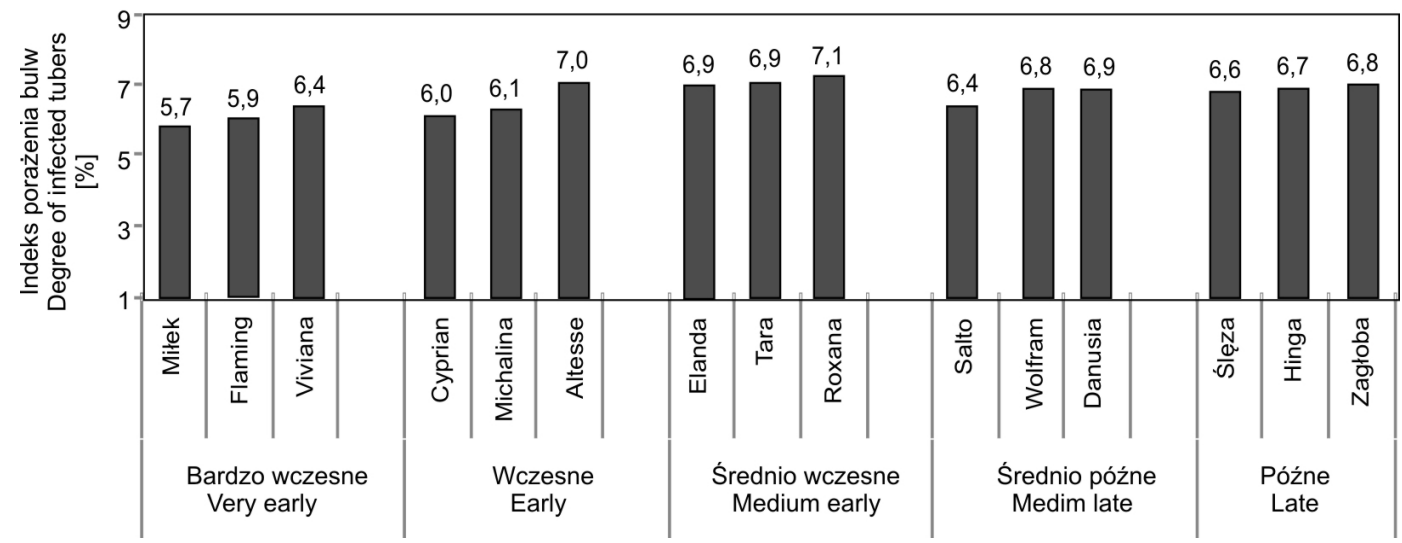

Rys. 3. Odmiany o najniższym nasileniu występowania sklerocjów - najwyższym indeksie porażenia bulw $\left[9^{\circ}\right]$

Fig. 3. Cultivars with the lowest intensity of sclerotia - the highest degree of infected tubers $\left[9^{\circ}\right]$

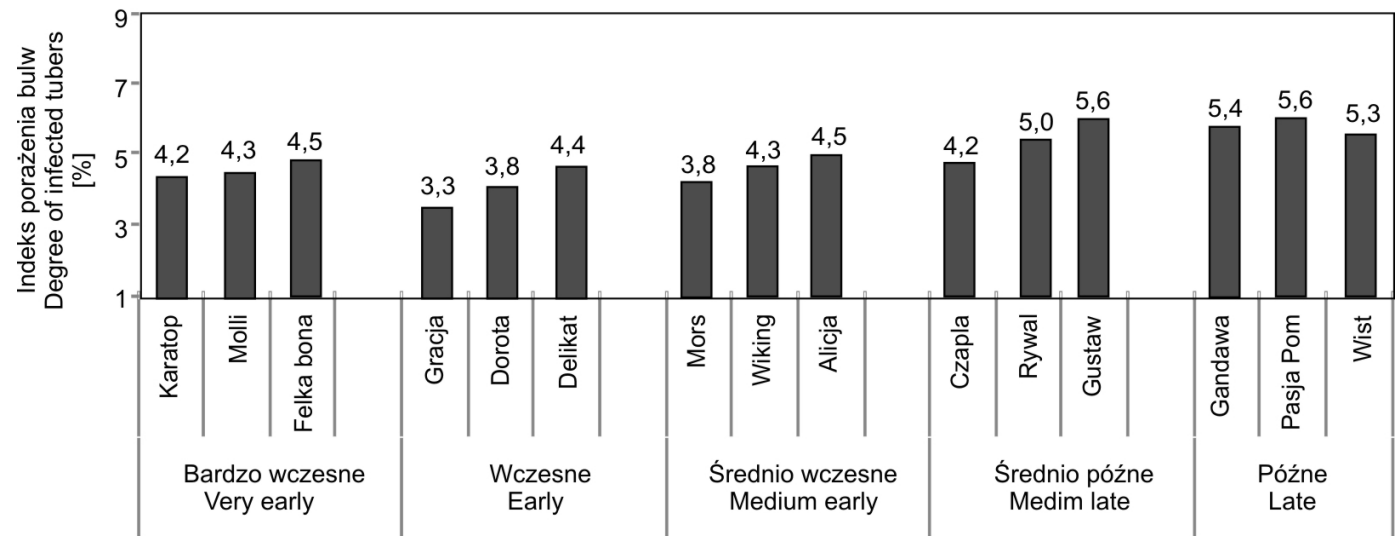

Rys. 4. Odmiany o najwyższym nasileniu występowania sklerocjów - najniższym indeksie porażenia bulw $\left[9^{\circ}\right]$

Fig. 4. Cultivars with the highest intensity of sclerotia - the lowest degree of infected tubers $\left[9^{\circ}\right]$

\section{Wnioski / Conclusions}

1. Badania potwierdziły genotypowe zróżnicowanie pod względem podatności/skłonności odmian do występowania ospowatości bulw.

2. Nie stwierdzono zależności między występowaniem ospowatości bulw a miejscem uzyskania odmiany. Wpływ kierunku użytkowania na tę cechą odnotowano tylko u odmian późnych.
3. Odmiany tej samej wczesności istotnie różnią się zarówno pod względem udziału bulw z ospowatościa, jak i nasilenia występowania sklerocjów na bulwach.

4. Odmianowa zmienność udziału bulw z ospowatością oraz zmienność nasilenia sklerocjów na bulwach kształtowały się różnie, a liczby klas jednorodnych pod względem każdej z tych cech były w poszczególnych grupach wczesności odmienne. 
5. Największym udziałem bulw ze sklerocjami charakteryzowały się odmiany: Aruba, Felka Bona, Justa, a najniższym: Cedron, Wolfram, Balbina.

6. Najwyższy stopnień porażenia, czyli najniższe nasilenie sklerocjów odnotowano u odmiany Roxana, natomiast odmianą najsilniej pokrytą sklerocjami była Gracja.
7. Spośród 165 ocenianych odmian, w wyróżniającej się grupie o najniższej podatności/skłonności do występowania ospowatości znalazły się pozostające w Krajowym Rejestrze odmiany: Viviana, Roxana, Hinga, Ślęza i Zagłoba.

\section{Literatura / References}

Bains P.S., Bennypaul H.S., Lynch D.R., Kawchuk L.M., Schaupmeyer C.A. 2002. Rhizoctonia disease of potatoes (Rhizoctonia solani): Fungicidal efficacy and cultivar susceptibility. American Journal of Potato Research 79: 99-106.

Bernat E. 2005. Występowanie ospowatości (Rhizoctonia solani) na bulwach wybranych odmian ziemniaka. Biuletyn Instytutu Hodowli i Aklimatyzacji Roślin 237/238: 195-199.

Choroszewski P. 1993. Wpływ warunków klimatycznych na porażenie bulw ziemniaka sprawcami chorób w latach $1979-1988$. Biuletyn Instytutu Ziemniaka 43: 113-129.

Djébali N., Tarhouni B. 2010. Field study of the relative susceptibility of eleven potato (Solanum tuberosum L.) varieties and the efficacy of two fungicides against Rhizoctonia solani attack. Crop Protection 29 (9): 998-1002.

Häni F., Popow G., Reinhard A. 1998. Ochrona roślin rolniczych w uprawie integrowanej. PWRiL, Warszawa: 130-131.

Kochman J., Węgorek W. 1997. Ochrona roślin. Plantpress, Kraków: 525-526.

Kućmierz J., Kurzawińska H., Wesołowska J. 1993. Wpływ terminu i gęstości sadzenia na występowanie rizoktoniozy (Rhizoctonia solani Kühn) na kilku odmianach ziemniaka. Zeszyty Naukowe Akademii Rolniczej w Krakowie 287, Ogrodnictwo 21: $105-114$.

Lenc L. 2006. Wpływ podkiełkowywania sadzeniaków na występowanie Rhizoctonia solani Kühn na kiełkach i bulwach sześciu odmian ziemniaka uprawianego w systemie ekologicznym. Journal of Research and Applications in Agricultural Engineering 51 (2): 104-107.

Lehtonen M.J. 2009. Rhizoctonia solani as a Potato Pathogen - Variation of Isolates in Finland and Host Response. Academic dissertation in plant pathology. Faculty of Agriculture and Forestry, University of Helsinki, Finland, 81 pp.

Lutomirska B. 2007. Wpływ odmiany i czynników meteorologicznych okresu wegetacji na ospowatość bulw ziemniaka. [The influence of cultivar and meteorological factors during vegetation season on black scurf of potato tubers]. Progress in Plant Protection/Postępy w Ochronie Roślin 47 (2): 173-177.

Lutomirska B. 2010. Wpływ ospowatości sadzeniaków ziemniaka na akumulację plonu oraz występowanie objawów porażenia przez Rizoctonia solani Kühn na roślinach i bulwach potomnych. [Influence of seed tuber infestation with black scurf on potato yield and symptoms of Rhizoctonia solani on plant and progeny tubers]. Progress in Plant Protection/Postępy w Ochronie Roślin 50 (1): $230-235$.

Lutomirska B., Jankowska J. 2013. Ospowatość bulw zaawansowanych materiałów hodowlanych ziemniaka. [Black scurf in tubers of the potato advanced breeding material]. Progress in Plant Protection/Postępy w Ochronie Roślin 53 (4): 789-795.

Mańkowski D.R. 2008. System SAS w badaniach rolniczych. Materiały szkoleniowe. Instytut Hodowli i Aklimatyzacji Roślin, Radzików, 114 ss.

Pietkiewicz J., Choroszewski P. 1983. Wstępna ocena reakcji odmian na niektóre choroby skórki bulw. Biuletyn Instytutu Ziemniaka 29: 129-139.

Platt H.W., Canale F., Giménez G. 1993. Effects of tuber-borne inoculum of Rhizoctonia solani and fungicidal seed potato treatment of plant growth and Rhizoctonia disease in Canada and Uruguay. American Potato Journal 70: 553-559.

Roztropowicz S. (red.). 1999. Metodyka obserwacji, pomiarów i pobierania prób w agrotechnicznych doświadczeniach z ziemniakiem. Instytut Hodowli i Aklimatyzacji Roślin, Oddział w Jadwisinie, 50 ss.

Townsend G.R., Heuberger J.W. 1943. Methods for estimating losses caused by diseases in fungicide experiments. Plant Disease Reporter 27: 340-343.

Tsror L. 2010. Biology, epidemiology and management of Rhizoctonia solani on potato. Journal of Phytopathology 158: 649-658.

Turka I., Bimšteine G. 2011. Importance of potato variety choice in integrated pest management. Book of abstracts (abstract No. F19). 24th NJF Congress: Food, Feed, Fuel and Fun and 2nd Nordic Feed Science Conference. Sweden, Uppsala, June 14-16, 2011. NJF Report 7 (3), p. 74.

Woodhall J.W., Lees A.K., Edwards S.G., Jenkinson P. 2008. Infection of potato by Rhizoctonia solani: effect of anastomosis group. Plant Pathology 57: 697-905.

Woodhall J.W., Lutomirska B., Peters J.C., Wharton P.S. 2013. Rhizoctonia solani anastomosis group 3 is predominant in potato tubers in Poland. Plant Disease 97 (9): 1245-1246. 